\title{
OUR TOP 10 BOOKS ON EDUCATION: FOR THE "EDUCATIONALLY-CURIOUS" BIBLIOPHILE
}

\author{
RICHARD JOHNSTONE \& MARLENE LE BRUN ${ }^{1}$
}

Ever have departmental or faculty money to purchase books on education for the staff library? Ever have time to sit back, read about, and consider issues of educational theory and not know where to begin?

In this new section of the Review, we list some of the more interesting books which we have found - or stumbled upon. Some of these books have given us useful teaching tips. Some have offered good introductions to educational theory and practice. Others have raised provocative concerns about the nature and direction of education which have caused us to stop in our tracks. In future editions of the Legal Education Review we hope to include reviews of books, reports, and monographs that address issues of interest to law teachers.

\section{OUR TOP 10}

We have divided the ten books we survey into three ad hoc categories: those which offer critical and analytical insights into educational theory; those which marry theory and practice; and those which provide useful teaching tips. Despite these rudimentary labels, teachers are reminded that good educational practice must be infused by sound educational theory and that an understanding of sound educational theory is ineffective unless and until it is translated into practice. In later editions we hope authors will also submit reviews of influential reports on the status of legal education in various jurisdictions. 


\section{THEORETICAL FRAMEWORKS AND PERSPECTIVES}

\section{Perspectives on Adult Learning and Development}

David Boud and Virginia Griffin have edited a rather unusual collection of essays which consider learning from the adult learners' perspective, Appreciating Adults Learning: From the Learners' Perspective. ${ }^{2}$ Although the set of papers appears eclectic, ranging from articles on the role of play in adult learning through to personal, developmental learning, and to self-directed learning, the articles are arranged around four themes: overlooked ways of thinking about learning (in which the authors highlight issues of subjectivity in education); personal development learning; learning in formal courses; and implications for learners and teachers. Although some of the essays may appear at first a bit "too fluffy" for us "tough-minded, rigorous academics in law", the book is important for a number of reasons, most obviously because it reminds us of the need to focus on the perspective of learning which our students experience. As Boud and Griffin state,

"Only learners can learn and whatever knowledge is generated about learning must, at some level, be accessible and have meaning for them.

If learners read about other learners having experiences similar to their own, they will be able to understand themselves better and be able to learn more effectively. At least, they will be comforted to know that they are not the only ones in the world who have their struggle.

If we are to be effective teachers and facilitators of learning, it is helpful for us to see things from the point of view of (the learner). If, ... the most important thing for teachers to do is to ascertain what the learner already knows and teach accordingly, it behoves us to find out not only what the learner knows, but what the world looks like from his or her perspective." 3

\section{Developments in Cognitive Science}

Lauren Resnick's edition Knowing, Learning, and Instruction: Essays in Honour of Robert Glaser $^{4}$ is not for the faint hearted. It is, however, well worth the effort involved in trying to come to terms with some of the exciting developments in cognitive science, which approach emphasises how knowledge is constructed, dependent, and situated. According to Resnick, we are now in a position where we can consider issues of instruction from a solid 
informational base "about how knowledge and process interact to produce competent performance and with a flexible array of methods for examining learning in those disciplines - practical or academic — we might wish to teach."5

The essays in this collection are wide-ranging and probably not appropriate for a lazy summer afternoon reading. Of particular interest to law teachers are the chapters by Kintsch, who discusses how readers use text to create mental models, Chi and Bassock, who explore the use of examples by good and poor learners, Brown and Palincsar, who consider how group activities can support and improve learning, and Collins, Seely Brown, and Newman, who discuss how instruction can be arranged so that knowledge is acquired in the context in which it may be used.

\section{Legal Knowledge: The Use of Artistry in the Professions}

Donald Schön's Educating the Reflective Practitioner: Toward a New Design for Teaching and Learning in the Professions ${ }^{6}$ raises considerable concerns about the nature of professional education and the nature of knowledge in an engaging and thought-provoking style. Schön questions the privileged status which has been accorded systematic, usually scientific, knowledge. He argues for a place for the "deviant traditions of education" in which learning by coaching and learning by doing is emphasised. According to Schön, "[p]rofessional education should be redesigned to combine the teaching of applied science with coaching in the artistry of reflection-inaction."7

Schön begins to outline his reflective practicum approach by analysing education in architecture. He then illustrates his theoretical framework in discussions of musical performance, psychoanalytic supervision, and in counselling and consulting skills. In the final section of the book, he considers some of the implications of his ideas in the design of professional curricula.

Although Schön does not specifically propose how to develop a reflective practicum in law, the observations he makes about education for the professions hold promise for individuals who wish to develop curricula in law in which it is acknowledged and accepted that legal education is about more than the mere transmission of propositional knowledge. 
A good piece for those who wish to begin to consider the relationship between the nature of legal knowledge and educational practice.

\section{THEORY AND PRACTICE}

\section{Ramsden's “Bible”}

Paul Ramsden explains why we should be wary of recipe books in his Learning to Teach in Higher Education, ${ }^{8}$ possibly the best known book on tertiary teaching to be published in the last few years. Ramsden resists the temptation to provide easy solutions to the everyday problems facing tertiary teachers, arguing that "a clear definition of problems in education is more important than the provision of solutions." 9 Since teaching and learning are inextricably linked, teaching and learning cannot simply be improved by focusing on the activities of the individual teacher. We need also to focus our attention on courses, departments, and tertiary institutions themselves - the environment within which the teacher works and the "system of ideas which that environment represents." ${ }^{10}$ As a result, we need to do more than just help teachers acquire skills in, for example, lecturing, running small groups, setting examination papers, and so on. The real issue is for teachers to understand how to employ various skills and methods, which themselves are useful only if teachers have a clear awareness of key educational principles.

Ramsden's aim, therefore, is to assist teachers change their understanding about teaching so that they can reflectively apply knowledge to the right problems so as to find their own answers. A central idea in the book is that teachers can improve their teaching by studying how their students go about learning. Ramsden defines learning as the "ways in which learners understand, or experience, or conceptualise the world around them."11 The aim of teaching is to make learning possible. Thus, each and every aspect of teaching should be judged against the criterion of whether it can reasonably be expected to lead to the kind of student learning desired by the teacher.

Consequently the first seven chapters (Part 1 of the book) help teachers think about their students' learning and their own understanding of teaching by discussing general principles of 
learning and teaching. Chapter 2 examines some of the different ways in which teachers understand teaching in higher education. Chapters 3, 4, and 5 explore what educationalists have learned from empirical studies of teachers' and students' experiences of learning and teaching in tertiary institutions. Their particular concern is with how and what students learn in different academic disciplines and with what students consider to be effective teaching. These are important chapters because they locate Ramdsen as an educationalist working within the "approach to learning" school of learning theory, to be contrasted with the work, for example, of cognitive psychologists. Chapters six and seven draw together these experiences of teachers and students to develop a set of principles for effective teaching in tertiary education.

Part 2 of the book (chapters eight to ten) link theory and practice. They cover three of the recurrent issues in teaching: designing courses ("What we should teach?”); selecting teaching methods ("How we should teach it?"); and assessing students ("How we can decide students have learned from what we have taught them?”). It is here that Ramsden's concern not to provide simple recipes becomes most apparent. Rather than discussing the range of possible teaching and assessment methods, he shows how different teachers in different subjects have applied the basic principles of teaching and learning set out in the book to real situations. Ramden provides some wonderful case studies of good teaching practice. While there are hardly any examples of good law teaching, these chapters are most useful; they can act as a catalyst to stimulate teachers to think through the central principles of teaching and learning and to apply them to their own teaching.

Part 3 (chapters 11 and 12) discusses the evaluation of teaching and institutional strategies to improve teaching. Evaluation is a means of understanding the effects of teaching on students' learning. ${ }^{12}$ Ramsden shows how, in all the case studies of good teaching practice discussed in his earlier chapters, good teachers are always evaluating themselves. Ramsden is emphatic that evaluation is not something which is done to teachers by university administrators but rather is something done by teachers to improve their teaching competence and their students' understanding. ${ }^{13}$ Building on the principles enunciated in part 1 of the book, Ramsden discusses at length the difficulties in combining this form 
of evaluation with strategies designed to make teachers accountable to their students, university administrators, and the public.

Ramsden's book is eminently readable and, through the powerful way in which it links important theory with practice, should enable all law teachers to reflect upon and improve their teaching and their students' learning.

\section{Issues in Assessment}

Derek Rowntree's book, Assessing Students : How Shall We Know Them ? $^{14}$ is acknowledged by many, including Ramsden, as the best book on assessment. Rowntree's book is in the same educational mould as Ramsden's. Rowntree defines assessment as getting to know students and the quality of their learning. It is a human encounter in which teachers and students find out about each other and about themselves. Rowntree's definition of assessment is helpful because it considerably broadens the understanding of assessment that many law teachers in Australia appear to hold. Assessment in this definition includes both formal and informal assessment. It can be descriptive (the student "understands the basic principles") and/or judgmental ("the student is good at property law”). Formative assessment can lead to diagnostic appraisal (identifying a student's strengths and weaknesses, recognising emerging needs and interests, and helping the student to take further developmental action). Summative assessment involves grading students. Assessment is not just something done to students after they have been taught a course it should be integrated into their learning experiences. Rowntree reminds us that

[i]f we wish to discover the truth about an educational system, we must look into its assessment procedures. What student qualities and achievements are actively valued and rewarded by the system? How are its purposes and intentions realised? To what extent are the hopes and ideals, aims and objectives professed by the system ever truly perceived, valued and striven for by those who make their way within it? The answers to such questions are to be found in what the system requires students to do in order to survive and prosper. The spirit and style of student assessment defines the de facto curriculum. ${ }^{15}$

Rowntree notes that issues of assessment have the potential to dominate all aspects of teaching and learning - the development of aims and objectives, the design of learning experiences, the 
sequence and structure of a course, and the evaluation and improvement of teaching. Where Rowntree's book differs from most of the other writings on assessment is that it not only addresses the issue of "how" to assess (well canvassed in the literature), but examines why we assess students - the philosophical dimension of assessment.

Rowntree explores five dimensions of assessment. ${ }^{16}$ The first (chapters 2 and 3 ) raises the question of why we assess students and discusses the side effects or consequences of assessment. The second considers what we assess in the sense of determining what we are looking for, or remarking upon, when we assess people's work. The third addresses how we assess, which involves selecting, from all the available means for learning about people, "those we regard as being most truthful and fair for various sorts of valued knowledge." The fourth focuses on how we interpret assessment. How do we make sense of the outcomes of the observations, impressions or measurements we gather through the means we employ? How do we attach meaning to the "raw" events of assessment? The final issue looks at how we respond to student assessment. How do we find appropriate ways of expressing our response to an assessment task and communicate it to our students and others?

Rowntree's book, written in a most engaging style, is quite inspirational in the subtle, inventive, and humane approach it takes to teaching.

\section{Group Learning}

David Jacques' book on learning in groups ${ }^{17}$ has been written for those who wish to improve student learning through reducing their reliance on the lecture method. It has also been written to enable students to make their own meaning of educational material though collaborative learning. Jacques argues that teaching and learning in small groups has a valuable part to play in student learning because it allows students to negotiate meanings, express themselves in the language of a subject, acquire skills such as listening, presenting ideas, and persuading, and develop abilities for cooperative work in later life. He suggests that many teachers who wish to give students more opportunities to express themselves in the classroom are frustrated by their lack of expertise in 
understanding and facilitating group processes. The book, therefore, aims to promote understanding of group method, to develop skills for teachers and students alike, and to widen the range of possible group experiences.

The book starts in chapters 1 and 2 by looking at theories about, and research into, group behaviour. Jacques does not see himself within any particular school of group theory. Rather, he adopts an eclectic approach, drawing on various research and theoretical approaches to develop insights into group learning. Thus, topics in the first two chapter range from psychodynamic theory to interaction theory, definitions of groups and discussions of their properties, types of discussions, the role of leadership and similar issues. Two short chapters on learning (chapter 3) and communication in groups (chapter 4) follow, which once again assume an approach which ranges across different theoretical research into learning and group communication.

Chapter 5 concerns itself with the kinds of aims and objectives that are suitable for learning in groups; in particular, it relates these aims to those of academic learning. Chapter 6 provides a framework to relate these aims and objectives to corresponding tasks and techniques. According to Jacques, ${ }^{18}$ tasks specify the activities in which students are individually or collectively engaged (for example, applying legal rules to the facts of a problem, arguing, discussing etc), while techniques are "the ensemble of tasks, rules and procedures which comprise a coherent educational experience.” In this chapter he describes in some detail a range of techniques and outlines the principle aims they are designed to serve as he argues strongly for a variety of teaching methods. Jacques arbitrarily groups techniques into three categories (and within each category he organises the techniques from tutor control to student freedom):

- those concerned with mainly cognitive objectives (knowledge, comprehension, application, problem-solving, analysis, and evaluation):

- controlled discussion; step-by-step discussion; buzz groups; pyramids; crossover groups; horseshoe groups; seminars; syndicates; case studies; peer tutoring, etc;

- those involving creative objectives (seeing new relationships, connecting the emotional and the intellectual, producing 
imaginative solutions, etc):

— brainstorming; free or associative discussion, etc; and

- those developing individual or group awareness, personal growth, communication skills, participation and those which facilitate the breaking down of interpersonal barriers:

— role plays; simulations; etc.

Chapter 7 builds on the previous chapter to examine the range of skills the teacher needs in order to prepare for, and to, handle group interaction. In particular he discusses the types of interventions a teacher might make during the course of a group activity. In Chapter 8 Jacques, then, addresses the place of learning in groups in the social and educational environment of the institution, and he illustrates the basic principles with case studies. Lastly, he discusses the evaluation of small group teaching and provides suggestions for training methods and activities to improve learning in groups.

All in all, Jacques's book well assists teachers who are interested in broadening the range of learning experiences available to their students - and he does so within a well constructed theoretical framework.

\section{The HERDSA Green Guide Series}

The Higher Education Research and Development Society of Australasia (HERDSA) has produced a series of very helpful, userfriendly, easily digestible Green Guides on topics such as supervising postgraduates, improving student writing, implementing student self-assessment, conducting tutorials, lecturing, and assessing student performance. The Guides provide general theoretical frameworks for the practical tips they contain. To give an example: Crooks' guide on assessing student performance is divided into three chapters: Why Assess? (a pithy summary of the reasons for assessment in education); Important Guiding Principles (a brief discussion of key assessment principles); and Some Practical Suggestions (which includes how to give constructive feedback to students and how to match assessment with course objectives). Information on the series can be obtained from HERDSA, c/- TERC, UNSW, PO Box 1, Kensington, NSW Australia. 


\section{TEACHING TIPS}

\section{How to ... by Newble and Cannon}

An illustrated, basic, practical, and short guide to the day to day aspects of teaching is contained in David Newble and Robert Cannon's A Handbook for Teachers in Universities and Colleges: A Guide to Improving Teaching Methods. ${ }^{19}$ Although the final chapter of the handbook does consider some aspects of learning theory, the book excels as a "how to" manual. Its topics range from curriculum planning through to teaching in large and small groups, and practicals. The development of instructional materials and teaching aids are summarised, and pointers are given on assessment. One chapter is even devoted to presenting conference papers - advice which many new (and some seasoned) law teachers may wish to heed. A little gem.

\section{McKeachie’s Beginners' Guidebook}

McKeachie's Teaching Tips : A Guidebook for the Beginning College Teacher, first published in 1951, is now in its eighth edition, suggesting that it has stood the test of time and has provided generations of teachers with useful tips to improve their teaching. ${ }^{20}$ The book was originally written to answer questions posed by new teachers "to place them at ease in their jobs, and to get them effectively started in the classroom."21 Subsequent editions have revised the book to cater for the reader who has progressed beyond the novice stage. Unlike Ramsden, Rowntree, and Jacques, chapters tend to begin with "tips;" however, these are usually followed by a discussion of the research and theory underlying the tips. McKeachie's base is in cognitive and instructional theory, giving his work a different theoretical slant when compared with Ramsden and Rowntree.

The book is divided into six parts. The first is all about "getting started" (eg course preparation, meeting the class for the first time, etc). Part I1 looks at discussion methods and part I11 at the "basic skills" of lecturing, testing, and grading. Part IV is about teaching techniques, tools, and methods (eg one-on-one teaching and counselling, projects and independent study, audio-visual 
techniques, simulations and the case method, teaching writing, etc). Part V discusses teaching large classes while the last part examines perspectives on teaching and the teaching environment (motivating students, evaluating students, setting and maintaining ethical standards in teaching, etc).

The book is ideal for the teacher who is looking for new ideas to implement in line with the broad principles of teaching and learning gleaned from other resource books.

\section{Interesting Ways to ...}

On yet another plane is Graham Gibbs, Sue Habeshaw and Trevor Habeshaw's Interesting Ways to Teach series, ${ }^{22}$ which are recipe books in the sense that they give very useful, practical suggestions on teaching, but without going into educational theory. For that reason, one should use them with caution, although safe in the knowledge that all of the methods suggested are "tried and true.” Each book provides a list of things to do, whether it be in a large "lecture," a small seminar or tutorial, in assessing students, or in evaluating teaching. Most suggestion include a description of the activity, its advantages and disadvantages, and guidelines for its effective use.

1 Senior Lecturers in Law, The University of Melbourne, and Griffith University respectively.

2 D Boud \& V Griffin, Appreciating Adults Learning: From the Learners' Perspective (Kogan Page, 1987).

Ibid 12.

4 L Resnick (ed), Knowing, Learning, and Instruction: Essays in Honour of Robert Glaser (Lawrence Erlbaum, 1989).

Ibid 1.

6 D Schön, Educating the Reflective Practitioner: Toward a New Design for Teaching and Learning in the Professions (Jossey-Bass, 1987).

Ibid xii.

8 P Ramsden, Learning to Teach in Higher Education, (Routledge, 1992).

9 Ibid xi.

$10 \quad$ Ibid 7.

11 Ibid 4.

12 Ibid 217.

13 Ibid.

14 D Rowntree, Assessing Students : H m Shall We Know Them? (Kogan Page, 1987 rev ed).

15 Ibid 1

16 Ibid 11. 
D Jacques, Learning in Groups (2 ed) (Kogan Page, 1991).

Ibid 75.

19 D Newble \& R Cannon, A Handbook for Teachers in Universities and Colleges: A Guide to Improving Teaching Methods (Kogan Page, 1989).

20 WJ McKeachie, Teaching Tips : A Guidebook for the Beginning College Teacher, (8 ed) (DC Heath and Company, 1986).

21 Ibid vii.

22 G Gibbs, S Habeshaw, \& T Habeshaw, 53 Interesting Things to Do in Your Lectures, (Technical and Educational Services Ltd, 1987); 53 Interesting Things to Do in Your Seminars and Tutorials (Technical and Educational Services Ltd, 1984); 53 Interesting Ways to Appraise Your Teaching (Technical and Educational Services Ltd, 1988); S Habeshaw, G Gibbs \& T Habeshaw, 53 Interesting Ways to Assess Your Students (3rd ed) (Technical and Educational Services Ltd, 1993). 